\title{
PENGARUH GAYA KEPEMIMPINAN TERHADAP KOMITMEN ORGANISASI KARYAWAN UKM DI WILAYAH DEPOK JAWA BARAT
}

\author{
Dede Suryanto ${ }^{1}$ \\ Wulan Prihatiningsih ${ }^{2}$ \\ 1,2 Laboratorium Keuangan dan Perbankan, Program Vokasi UI, d.suryanto@ui.ac.id, wulan.dvd@gmail.com
}

\section{Diterima : 12 November 2015}

Layak Terbit : 29 Desember 2015

\section{Abstrak}

Komitmen organisasi merupakan keadaan psikologis yang mencirikan hubungan karyawan dengan organisasi dan memiliki implikasi bagi keputusan untuk melanjutkan keanggotaan dalam organisasi. Karyawan dengan komitmen tinggi merupakan harta berharga bagi perusahaan untuk bisa melanjutkan operasional perusahaan sehingga perusahaan bisa mempertahankan kelangsungan hidupnya. Penelitian ini mengusulkan bahwa komitmen organisasi dipengaruhi oleh gaya kepemimpinan. Hipotesis diuji menggunakan data yang diperoleh dari 60 karyawan (responden) di beberapa UKM wilayah Kota Depok. Hasil yang diperoleh dengan metode regresi logistik menunjukkan bahwa transformational leadership style berpengaruh positif terhadap affective commitment dan tidak berpengaruh pada normative commitment, transactional leadership style tidak berpengaruh terhadap continuance commitment, dan passive/avoidant leadership style tidak mempengaruhi affective commitment.

Kata Kunci: tranformasional, transaksional, passive/avoidant, komitmen afektif, komiitmen normatif, komitmen keberlanjutan.

\begin{abstract}
Organizational commitment is a psychological state that characterizes employee relationship with the organization. It has implication for the decision to continue membership in the organization. Employee with high commitment is a valuable asset in operating the company in order to maintain Company's sustainability. This research proposes that organizational commitment is influenced by leadership style. The hypothesis is tested using data obtained from 60 respondents who work in Small and Medium enterprises in Depok. The results shows that transformational leadership style affects positively on affective commitment but it doesn't affect normative commitment. Besides that, transactional leadership style doesn't affect continuance commitment, while passive / avoidant leadership style does not affect affective commitment.
\end{abstract}

Keyword : tranformasional, transaksional, passive/avoidant, komitmen afektif, komiitmen normatif, komitmen keberlanjutan.

\section{PENDAHULUAN}

Data Badan Pusat Statistik (2010) menyatakan bahwa unit Usaha Kecil dan Menengah (UKM) menjadi pelaku usaha terbesar dengan prosentasenya sebesar 99,99\% dari total usaha nasional pada tahun 2011. UKM merupakan suatu usaha yang dijalankan oleh kurang dari 4 tenaga kerja disebut industri rumah tangga, kemudian jika usaha dijalankan oleh 5-19 pekerja digolongkan kepada industri kecil dan jika usaha dijalankan oleh 20 - 99 pekerja digolongkan industri menengah (BPS). Kontribusi UKM terhadap perekonomian 
Indonesia dari tahun 2010 ke 2011 antara lain adalah meningkatkan PDB Nasional sebesar $0,1 \%$ meningkatkan penerimaan devisa sebesar $0,62 \%$, meningkatkan penyerapan tenaga kerja sebesar 0,22\%, dan meningkatkan pembentukan investasi sebesar 1,85\% (BPS, 2010). Dari data tersebut dapat disimpulkan bahwa UKM memiliki peran yang luas terhadap perekonomian Indonesia, namun nilai kontribusinya relatif rendah.

\section{Penelitian "Peningkatan Kinerja}

Usaha Kecil dan Mengah (UKM) Kluster kerajinan di Kota Depok Menggunakan The House Model" yang dilakukan oleh Putri Wahyuningrum, Anggraini Sukmawati, dan Lindawati Kartika (2014), menjelaskan terdapat beberapa masalah yang dihadapi UKM saat ini, permasalahan utama yang dihadapi oleh mayoritas UKM di Kota Depok berdasarkan penelitian tersebut adalah rendahnya komitmen karyawan terhadap organisasi (organization commitment). Mathieu and Zajac (1990) menyebutkan bahwa organization commitment dipengaruhi oleh leadership style. Dalam penelitian tersebut juga dijelaskan bahwa faktor utama penyebab rendahnya organization commitment adalah kurangnya pengawasan dan motivasi karyawan. Kedua hal ini merupakan fungsi dari kepemimpinan, sehingga dibutuhkan gaya kepemimpinan yang tepat sebagai salah satu alternatif solusinya.

Mengacu pada model Full Range Leadership yang dikembangkan oleh Bass (1990, 1999), terdapat 3 macam gaya kepemimpinan, yaitu tranformasional, transaksional, dan passive/avoidant. Menurut
Yammarino \& Bass (1990), kepemimpinan transformasional ditandai sebagai seseorang yang mengungkapkan dengan jelas visi masa depan yang bisa disosialisasikan kepada rekan kerja dan subordinatnya, bisa menstimulasi subordinat, dan memberikan perhatian pada perbedaan antar individu. Selain itu, pemimpin dengan gaya transformasional biasanya memberdayakan dan mengevaluasi subordinat dengan menggunakan karisma, intelektual, dan perhatian terhadap individu untuk mencapai kinerja yang lebih baik. Sedangkan kepemimpinan transaksional pada intinya adalah menekankan imbalan untuk memotivasi subordinatnya (Bass, 1990). Gaya kepemimpinan yang ketiga adalah passive/avoidant style yaitu pemimpin yang bersifat pasif terhadap penyelesaian masalah yang potensial, akan bereaksi hanya pada saat kondisi kronis, pada umumnya pemimpin yang memiliki gaya pasif cenderung menghindari tanggung jawab dalam supervising dan decision making (Clinebell, 2013).

Ketiga gaya kepemimpinan di atas diperlukan dalam sebuah organisasi sebagai salah satu alternatif solusi untuk menciptakan organizational commitment. Organization commitment diartikan sebagai keadaan psikologi yang mencirikan hubungan karyawan dengan organisasi dan memiliki implikasi atas keputusan keberlanjutan keanggotaan dalam sebuah organisasi (Meyer and Allen, 1991, 1997). Tiga komponen dari organizational commitement antara lain adalah affective commitment (AC), continuance commitment $(\mathrm{CC})$, dan normative commitment 
(NC). Jurnal karya Sharon Clinebell, dkk tahun 2013 dengan judul "Impact of Leadership Style On Employee Organizational Commitment” sebagai jurnal acuan utama dalam penelitian ini manyatakan leadership style transformational dan transactional secara positif berpengaruh terhadap organizational commitment serta passive/avoidant style secara negatif mempengaruhi organization commitment. Berdasarkan literature tersebut, dapat disimpulkan bahwa permasalahan kurangnya pengawasan dan motivasi karyawan yang berdampak pada rendahnya organizational commitment karyawan terhadap organisasi dapat diperbaiki melalui penyesuaian gaya kepemimpinan. Dengan alasan tersebut, peneliti tertarik untuk melakukan penelitian tentang pengaruh leadership style terhadap organization commitment.

Penelitian ini bertujuan untuk melakukan studi kasus terhadap UKM di Kota Depok, Jawa Barat. Artikel "Kontribusi Usaha Mikro, Kecil, dan Menengah (UMKM) dalam Penyerapan Tenaga Kerja” oleh Sudarno (2012) menyatakan UMKM di wilayah Depok Jawa Barat mampu menyerap 73\% angkatan kerja. Dalam hal ini UMKM berkontribusi relatif besar terhadap perekonomian rakyat tetapi masih mengalami banyak kendala dan permasalahan. Sehingga perlu adanya pengkajian mengenai akar permasalahan yang dihadapi UMKM di Depok, Jawa Barat guna memperoleh alternatif solusi untuk meningkatkan kontribusi UMKM tersebut. Melalui penelitian ini, peneliti mencoba mengkaji permasaalahan sumber daya manusia dengan berfokus pada gaya kepemimpinan founder atau pemimpin UKM terhadap komitmen karyawan terhadap organisasi (UKM).

\section{TINJAUAN PUSTAKA DAN KERANGKA} TEORI

Kepemimpinan (leadership) merupakan suatu proses dimana seseorang mempengaruhi pengikut untuk mencapai tujuan dan mengarahkan organisasi dengan cara yang membuatnya lebih kohesif dan koheren. Pemimpin melaksanakan proses ini dengan menerapkan pengetahuan dan keterampilan kepemimpinan mereka (Calrk, 1997).

Full Range Leadership Model

Full range leadership model yang dikembangkan oleh Bass (1990,1999) menyebutkan bahwa terdapat 3 gaya kepemimpinan, yaitu transformasional, transaksional, dan passive/avoidant. Penelitian ini menggunakan teori full range leadership model yang dikemukakan oleh Bass dalam menjelaskan pengertian macam-macam gaya kepemimpinan, karena teori tersebut mampu menggambarkan fenomena kepemimpinan yang terjadi di lapangan. Tidak semua pemimpin atau founder UKM secara aktif mengontrol dan mengawasi kinerja karyawannya, sehingga dengan adanya tipe kepemimpinan pasif di dalam teori full range leadership model menjadikan alasan penelitian ini menggunakan teori tersebut sebagai acuan penelitian.

Kepemimpinan Transformasional Kepemimpinan transformasional terjadi ketika pemimpin meluaskan dan 
meningkatkan kepentingan karyawan dan ketika mereka menghasilkan kesadaran serta persetujuan melalui kepentingan mereka sendiri untuk kebaikan kelompok tersebut (Bass, 1990). Perbedaan antara kepemimpinan transformasional dan transaksional adalah pemimpin dikatakan transformasional ketika pemimpin tersebut mampu menciptakan citacita dan misi kelompok, dan ketika mereka menggerakkan karyawan untuk memperlihatkan perilaku menarik sense of values dari pengikutnya dan bisa mengarahkan pengikutnya untuk melihat visi yang lebih tinggi dan untuk mendorong karyawan agar karyaawan mampu menekan dirinya sendiri untuk mencapai visi (Burn, 1978). Kondisi dalam kepemimpinan transformasional tersebut di atas membuat followers (karyawan) termotivasi dan terinspirasi untuk mencapai apa yag diekspektasikan oleh pemimpin. Menurut model yang dikembangkan oleh Bass (1990, 1999), dimensi dari kepemimpinan transformasional sebagai berikut:

\section{a. Idealize influence and idealize behavior}

Idealize influenze mengacu pada tingginya tingkat percaya diri yang menghasilkan rasa bangga, respek, dan kepercayaan kepada pemimpin (Flynn, 2009). Sedangkan idealize behavior dikategorikan masih dalam item atribut yang sama dengan idealize influence, yaitu merepresentasikan pemimpin yang bekerja keras untuk meningkatkan kepercayaannya dalam mempengaruhi sikap karyawan (Flynn, 2009).

\section{b. Inspirational motivation}

Merepresentasikan kemampuan pemimpin untuk bertindak sebagai role model

dan menginspirasi subordinate untuk menekankan usaha mereka terhadap shared visions (Bass, 1999, p.19). Dimensi inspirational motivation menjelaskan bahwa pemimpin memberikan arti dan tantangan bagi orangorang yang dipimpin dengan maksud menaikkan semangat dan harapan, menyebarkan visi, komitmen pada tujuan dan dukungan tim (Bass \& Avolio, 1994, dalam Tsachnnen-Moran, 2003).

c. Intellectual stimulation

Intellectual stimulation mencakup kemampuan pemimpin untuk menantang pengikutnya agar ikut berfikir dalam proses menyelesaikan masalah dengan cara memberikan harapan kepada pengikut untuk mempertimbangkan perbedaan perspektif dan membawa cara baru untuk membuat sesuatu terwujud (Clinebell, dkk., 2013).

\section{d. Individual consideration}

Individual

menggambarkan perhatian terhadap subordinate untuk mencapai potensial mereka. Hal ini perlu adanya mengidentifikasi keperluan dan aspirasi dari setiap subordinate dan memanjakan dalam coaching dan training (Clinebell, dkk., 2013). Bass dan Avolio (1994) mendefinisikan individual consideration sebagai tindakan pemimpin untuk memberikan bantuan, memberikan pelayanan sebagai mentor, memeeriksa kebutuhan individu untuk perkembangan dan peningkatan keberhasilan.

\section{Kepemimpinan Transaksional}

Kepemimpinan

transaksional cenderung beroperasi dalam batas-batas dan batas budaya yang ada, sementara para 
pemimpin transformasional sering bekerja menuju perubahan budaya sejalan dengan visi mereka (Bass, 1985). Jenis kepemimpinan transaksional sering disebut sebagai jenis kepemimpinan tradisional dan diberi nama berdasarkan pada argumen bahwa ada transaksi yang mendasarinya atau tawarmenawar antara manajer dan karyawan di mana pengikut diperkenalkan terhadap perilaku yang diharapkan dari pemimpin agar menjadi berhak atas kompensasi karena kepatuhan mereka terhadap persyaratan yang didalilkan. Seperti apa yang ditunjukan oleh Bass dalam gambaran tentang 20 tahun penelitian di lapangan, hubungan pemimpin dan pengikut hanya didasarkan pada kepentingan diri sendiri dan memerlukan proses pertukaran cost dan benefit (Bass, 1999). Berdasarkan pada Bass'model bahwa kepemimpnan transaksional ada dua teknik yang digunakan untuk tujuan pencapaian, yang dalam hal ini menjadi dimensi dari kepemimpinan transaksional yaitu:

a. Contingent reward

Contingent reward merepresentasikan hubungan berdasarkan pada punishment dan reward sebagai imbalan dari kinerja (Flynn, 2009). Bass (1990) menyatakan bahwa ketika menggunakan contingent reward, seorang pemimpin menyelesaikan seuatu pekerjaan atau tugas dengan membuat perjanjian kenaikan gaji bagi karyawan yang bekinerja baik, begitu sebaliknya memberikaan hukuman bagi kinerja yang buruk. Dengan kata lain, contingent reward didefinisikan melalui tindakan pemimpin yang memotivasi karyawan dengan menggunakan reward dan punishment.

\section{b. Management by exception active}

Management by exception active didefinisikan sebagai tindakan pemimpin untuk mengungkap penyelewaengan atau penyimpangan atas kinerja followers (karyawan) (Flynn, 2009). Secara singkat bahwa dalam management by exeption active ini pemimpin mengawasi dan mencari deviasi atau penyimpangan kinerja karyawan terhadap aturan dan standard, serta mengambil tindakan korektif.

\section{Passive/Aoidant}

$$
\text { Yamarino dan Bass }
$$
merumuskan bahwa gaya kepemimpinan passive/avoidant ini sama dengan laissez-faire style, pemimpin cenderung melepaskan tanggung jawab mereka secara keseluruhan dan menjaga jarak dengan masalah yang dihadapi oleh followersnya (karyawan). Menurut bass (1999, p.11) bahwa passive/avoidant style memiliki satu dimensi yaitu :

\section{a. Management by exception passive}

Dimensi ini didefinisikan sebagai perilaku yang menggambarkan seorang pemimpin yang menunggu masalah muncul sebelum melakukan tindakan koreksi (Bass, 1999, p.11).

Dalam penelitian ini menggunakan teori Full range leadership model dikembangkan oleh Bass (1990,1999), yang menjelaskan bahwa terdapat tiga gaya kepemimpinan, yaitu transformasional, transaksional, dan passive/avoidant. Penelitian ini menggunakan teori tersebut karena teori tersebut mampu 
mendeskripsikan perilaku dan tindakan founder/pemimpin UKM Depok yang ditemui peneliti saat melakukan studi lapangan.

\section{Komitmen Organisasi (Organization Commitment)}

Banyak variasi definisi komitmen organisasi, tetapi secara singkat komitmen organisasi diartikan sebagai keadaan psikologis yang mencirikan hubungan karyawan dengan organisasi dan memiliki implikasi bagi keputusan untuk melanjutkan keanggotaan dalam organisasi (Meyer and Allen, 1991, 1997). Komitmen organisasi juga didefinisikan sebagai kekuatan relatif pengidentifikasian individu terhadap keterlibatannya dalam organisasi tertentu. Komitmen tersebut umumnya dapat ditandai dengan setidakn ya tiga faktor, yaitu keyakinan yang kuat dan penerimaan tujuan dan nilai-nilai organisasi, kesediaan untuk mengerahkan usaha yang cukup atas nama organisasi, dan keinginan yang pasti untuk mempertahankan organisasi keanggotaan (Balfour \& Wechsler, 1996; Bar- Hayim \& Berman, 1992; Hackett et al., 1994; Hunt \& Morgan, 1994; Meyer \& Allen, 1991; Mowday, et al., 1979; Porter, et al., 1974; Wiener \& Gechman, 1977). Porter, et al., (1974). Mengacu pada jurnal utama dalam penelitian ini, Meyer dan Allen mengusulkan konsep multidimensional menghasilkan 3 komponen dari komitmen organisasi (Meyer \& Allen, 1990, 1997; Lee et al, 2001; Meyer \& Herscovitch, 2001), sebagai berikut:

a. Komitmen Afektif (Affective Commitment) Komitmen afektif mengacu pada pengalihan emosional karyawan, identifikasi emosional karyawan, dan keterlibatan emosional karyawan dalam organisasi (Meyer \& Allen, 1991). Karyawan dengan komitmen afektif yang kuat cenderung melanjutkan pekerjaannya di organisasi tersebut karena keinginan mereka untuk melakukannya. Mowday, Steers, dan Porter (1979) mengusulkan ada empat kelompok yang diidentifikasi sehubungan dengan komitmen afektif, yaitu karakteristik pribadi, karakteristik pekerjaan, pengalaman bekerja, dan karakteristik struktural. Sebagian besar perhatian di bidang penelitian telah dikhususkan terutama untuk pengalaman bekerja yang diyakini sebagian besar dikelola dalam organisasi untuk mempengaruhi komitmen karyawan dengan cara yang diinginkan (Meyer \& Allen, 1988).

b. Komitmen Kelanjutan (Continuance Commitment)

Komitmen kelanjutan mengacu pada tindakan untuk mempekerjakan karyawan berdasarkan akumulasi dari biaya, seperti biaya pension, skill transferability, relokasi, dan self investment yang co-vary dengan keanggotaan organisasi (Meyer \& Allen, 1991). Ada dua faktor yang diidentifikasikan sebagai dampak perkembangan komitmen kelanjutan. Salah satunya adalah terkait dengan volume investasi yang dilakukan dan yang lain dipengaruhi oleh kelangkaan alternatif. Becker (1960) menyatakan teori side-bet telah menyediakan kesempatan untuk evolusi komponen ini sebagai elaborasinya bahwa karyawan tetap berkomitmen terhadap organisasi tertentu berdasarkan waktu dan usaha yang mereka habiskan untuk menguasai 
keterampilan khusus dan memperoleh pengalaman atau hubungan sosial yang tidak dapat direplikasi dengan mudah di tempat lain dan akan memerlukan investasi yang sangat besar untuk memulai, dengan kata lain, "Sunk Cost" yang dipertimbangkan untuk perluasan (Buciuniene \& Skudiene, 2008). Komitmen kelanjutan yang sama berkembang di bawah perkiraan kurangnya alternatif yang memaksa seorang karyawan untuk tetap dalam organisasi.

\section{c. Komitmen Normatif (Normative} commitment)

Komitmen Normatif merujuk pada perasaan karyawan atas kewajiban untuk tetap bersama dengan organisasi berdasarkan motivasi untuk menyesuaikan diri terhadap norma sosial (Meyer \& Allen, 1991). Karyawan dengan komitmen normatif tinggi merasa bahwa mereka harus tetap dengan organisasi. Komitmen normatif, sebagai kewajiban untuk tetap setia kepada satu organisasi, mampu berkembang jauh lebih awal dari kerja yang sebenarnya. Nilai-nilai keluarga, sosialisasi budaya, tradisi sejarah, dan berbagai faktor eksternal lainnya dapat mempengaruhi evolusi keadaan psikologis kewajiban dan keyakinan yang kuat bahwa salah satu harus setia kepada organisasi. Sama pentingnya adalah sosialisasi organisasi setelah memasuki organisasi, sikap dan nilainilai yang berbeda dipamerkan dan percaya bahwa lingkungan kerja dapat memiliki dampak pada persepsi dari pendatang baru.

Dalam penelitian ini, diprediksikan gaya kepemimpinan transformasional berpengaruh positif terhadap komitmen afektif (affective commitment) dan komitmen berdasarkan norma (normative commitment), gaya kepemimpinan transaksional berpengaruh positif terhadap komitmen kelanjutan (continuance commitment), dan gaya kepemimpinan pasif atau menghindar berpengaruh negatif terhadap komitmen afektif (affective commitment). Pengaruh gaya kepemimpinan transformasional terhadap komitmen organisasi karyawan secara umum lebih tinggi dibandingkan pengaruh gaya kepemimpinan transaksional terhadap komitmen karyawan. Penelitian sebelumnya menjelaskan bahwa pada dasarnya gaya kepemimpinan transformasional dan transaksional sama-sama mempengaruhi komitmen organisasi karyawan, tetapi pada level yang berbeda. Hal ini menjadi alasan kuat peneliti sebelumnya tidak melakuakan pengujian hipotesis mengenai hubungan gaya kepemimpinan satu persatu terhadap komitmen organisasi karyawan.

\section{MODEL PENELITIAN DAN PENGEMBANGAN HIPOTESIS}

Penelitian ini mengacu pada penelitian yang dilakukan oleh Clinebell (2013). Pada penelitian tersebut Clinebell (2013) meneliti pengaruh tiga gaya kepemimpinan yaitu transformasional, transaksional, dan passive/avoidant terhadap dimensi komitmen organisasi karyawan. Secara detail hipotesis yang diajukan dalam penelitian Clinebell (2013) tersebut adalah gaya kepemimpinan transformasional secara positif mempengaruhi tingkat komitmen afektif dan normatif, gaya kepemimpinan 
transaksional secara positif mempengaruhi tingkat komitmen kelanjutan, dan gaya kepemimpinan passive/avoidant secara negatif berpengaruh terhadap tingkat komitmen afektif. Kesimpulan dari pengujian terhadap ketiga.

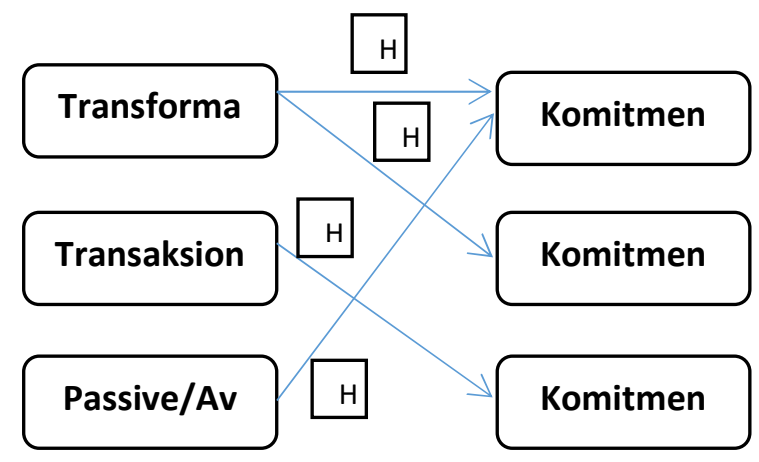

Berdasarkan model penelitian, maka hipotesis dalam penelitian ini sebagai berikut:

H1: Transformational leadership style berpengaruh positif terhadap tingkat affective commitment.

Pada penelitian sebelumnya telah ditetapkan bahwa secara umum gaya kepemimpinan transformasional memiliki pengaruh lebih tinggi terhadap komitmen karyawan dibanding gaya kepemimpinan transaksional. Hal ini menjadi alasan kuat peneliti sebelumnya tidak melakuakan pengujian hipotesis mengenai hubungan gaya kepemimpinan satu persatu terhadap komitmen karyawan.

H2 : Transformational leadership style berpengaruh positif terhadap tingkat normative commitment.

Pada penelitian yang sudah dilakukan, komitmen normatif mencoba untuk menjelaskan pola yang sama dari korelasi dengan anteseden terhadap salah satu komponen terlihat di dalam komitmen afektif.
Pada kasus mayoritas menyatakan hubungan yang lebih signifikan. Khususnya pada gaya kepemimpinan transformasional yang paling banyak ditemukan untuk memberikan pengaruh pada komitmen normatif.

H3: Transactional leadership style berpengaruh positif terhadap tingkat continuance commitment.

Pengaruh gaya kepemimpinan transaksional hanya dianalisis terhadap komitmen kelanjutan karena dalam penelitian sebelumnya mengatakan bahwa, gaya kepemimpinan transaksional lebih objektif dan merupakan pengembangan dari konsep economic exchange yang relevan terhadap komitmen kelanjutan.

H4: Passive/avoidant leadership style berpengaruh negatif terhadap tingkat affective commitment.

Dalam penelitian ini gaya kepemimpinan passive atau menghindar dihipotesiskan berpengaruh negatif terhadap komitmen afektif karena gaya kepemimpinan pasif atau menghindar memiliki definisi negatif dan diasumsikan tidak berpengaruh pada dimensi komitmen organisasi karyawan yang paling positif yaitu komitmen afektif.

\section{METODOLOGI PENELITIAN}

\section{Desain Penelitian}

Desain penelitian merupakan pondasi dari sebuah penelitian. Menurut Cooper (2011), desain penelitian mengekspresikan struktur dari permasalahan penelitian dan kerangka penelitian, orgainsasi, atau 
konfigurasi atas hubungan diantara variabel dalam penelitian, dan rencana penelitian yang digunakan untuk memperoleh fakta atau bukti di dalam hubungan. Cooper (2011) mengklasifikasikan desain penelitian menjadi tiga yaitu eksploratori, deskriptif, dan kausal.

$$
\text { Penelitian eksploratori sangat }
$$

berguna ketika peneliti tidak memiliki ide yang jelas tentang masalah yang mereka akan bertemu selama penelitian, melalui peneliti eksplorasi bisa mengembangkan konsep dengan lebih jelas, menetapkan prioritas, mengembangkan definisi operasional, dan memperbaiki desain penelitian akhir. Berbeda dengan penelitian eksplorasi, penelitian deskriptif merupakan studi yang lebih formal dan terstruktur dengan hipotesis yang dinyatakan secara jelas atau pertanyaan penelitian. Sedangkan penelitian kausal didefiinisikan sebagai A menimbulkan B atau A memaksa B terjadi, dengan kata lain penelitian kausal adalah penelitian untuk mengetahui pengaruh antar variabel (Cooper, 2011). Jenis penelitian ini adalah penelitian kausal karena peneliti ingin mencari tahu hubunhan antar variabel penelitian.

Subjek Penelitian

Dalam penelitian ini yang menjadi objek penelitian adalah pengaruh variabel gaya kepemimpinan (leadership style) terhadap komitmen organisasi (organization commitment). Gaya kepemimpinan yang diteliti terdiri dari 3 variabel yaitu tranformasional, transaksional, dan passive/avoidant yang masing-masing memiliki indikator atau dimensi yang berbeda. Sedangkan variabel dependennya adalah komitmen organisasi karyawan (organization commitment) yang terdiri dari 3 dimensi yaitu affective commitment (AC), continuance commitment (CC), dan normative commitment (NC). Responden penelitian ini adalah karyawan dari beberapa UKM yang berada di wilayah Depok, Jawa Barat.

\section{Metode Penelitian}

Metode penelitian adalah rencana dan struktur penelitian sehingga dipahami untuk memperoleh jawaban atas pertanyaan penelitian. Rencana diartikan sebagai keseluruhan skema atau program dari penelitian, meliputi daftar apa saja yang akan dilakukan oleh investigator mulai dari menulis hipotesis dan implikasi operasional terhadap hasil akhir dari analisis data (Cooper, 2011). Penelitian ini bersifat kausal, yaitu untuk melihat pengaruh sebab akibat antara 3 gaya kepemimpinan diantaranya adalah tranformasional, transaksional, dan passive/avoidant terhadap organization commitment karyawan. Data yang diperoleh akan diolah dengan metode statistik menggunakan program SEM.

Penelitian ini menggunakan metode penelitian gabungan antara metode kualitatif dan kuantitaif. Penelitian kualitatif didefinisikan sebagai penelitian yang didesain untuk menjelaskan kepada peneliti bagaimana (proses) dan mengapa (meaning) sesuatu terjadi. Penelitian kualitatif bertujuan untuk meneliti pada populasi atau sampel tertentu yang lebih menekankan pada aspek pemahaman secara mendalam terhadap suatu masalah (Cooper, 2011). Sedangkan penelitian kuantitatif mencoba pengukuran yang tepat 
dari sesuatu, seperti variabel. Selain itu penelitian kuantitatif sering digunakan untuk pengujian teori yang sudah ada. (Cooper, 2011). Pada penelitian ini digunakan metode penelitian gabungan karena penelitian kuantitatif akan ditunjang oleh penelitian kualitatif untuk mengeksplorasi dan memvalidasi variabel yang digunakan dalam penelitian sebelumnya untuk mengetahui apakah variabel yang ada dapat digunakan dalam penelitian ini.

\section{Metode Pengambilan Sampel (Sampling)}

Merujuk pada buku Business Research Methods (Copper, 2011) menyatakan sampling berarti melakukan seleksi terhadap beberapa elemen dari sabuah populasi. Populasi dalam konteks ini didefinisikan sebagai semua partisipan atau objek pada saat dilakukan pengukuran.

Dalam penelitian ini, metode sampling yang digunakan adalah probability sampling. yaitu simple random sampling. Probability sampling didefinisikan sebagai pengambilan sampel dimana setiap anggota populasi memiliki kemungkinan yang sama untuk menjadi responden, sedangkan simple random sampling adalah pengambilan sampel secara acak sederhana tanpa memperhatikan strata yang ada dalam populasi tersebut (Cooper, 2011). Penelitian ini menggunakan enam UKM bidang manufaktur di Wilayah Depok, Jawa Barat yang dipilih berdasarkan wilayah dan relasi baik yang sudah terjalin sebelumnya untuk memudahkan peneliti dalam mengumpulkan data primer.

\section{Metode Pengumpulan Data}

Dalam penelitian ini terdapat dua jenis data yang akan dikumpulkan yaitu data primer dan data sekunder. Data primer diambil secara langsung oleh peneliti untuk menjawab permasalahan spesifik yang dihadapi (Maholtra, 2004). Data primer diperoleh dari penelitian lapangan terhadap responden dengan instrument kuesioner. Teknik pengisian kuesioner yang digunakan adalah self administered questionnaire yang artinya pengisian kuesioner dilakukan oleh masing-masing responden. Sebelum responden mengisi kuesioner yang diberikan, peneliti akan memberikan penjelasan mengenai tujuan penelitian, konsep singkat penelitian, dan himbauan agar responden membaca petunjuk pengisian kuesioner secara cermat untuk mengurangi kemungkinan salah dalam pengisian kuesioner. Sedangkan data sekunder diperoleh dari berbagai sumber seperti jurnal, buku, artikel, dan situs website yang berkaitan dengan objek penelitian.

\section{Studi pustaka}

Studi pustaka digunakan oleh peneliti dengan tujuan untuk mengeksplorasi informasi yang berkaitan dengan penelitian. Adapun referensi yang dibutuhkan adalah jurnal utama yaitu Clinebell (2013) berjudul "Impact of Leadership Style on Employee Organizational Commitment", text book Business Research Method, dan jurnal atau penelitian setipe yang pernah dilakukan sebelumnya sebagai bahan critical review. 
Peneliti berharap dengan menggunakan studi pustaka diperoleh landasan teori untuk kepentingan penelitian.

\section{Kriteria Pemilihan Responden}

Pengisian kuesioner dilakukan oleh responden yang statusnya adalah sebagai karyawan di UKM wilayah Depok,Jawa Barat. Pemilihan responden dilakukan dengan menggunakan metode simple random sampling. Hal ini didasarkan pada alasan bahwa peneliti ingin mengetahui gaya kepemimpinan yang dapat meningkatkan organizational commitment karyawan dengan tidak memandang gender, tingkat jabatan, dan lain-lain.

Variabel Penelitian

Variabel penelitian adalah symbol sebuah event, tindakan, karakteristik, sifat, atau atribut yang bisa diukur dan ditetapkan nilainya (Cooper, 2011). Penelitian ini menggunakan variable yang diperoleh dari penelitian yang dilakukan oleh Clinebell pada tahun 2013.

a. Variabel Independen

Cooper (2011) dalam bukunya Business Research Method menyebutkan bahwa variable independen adalah variable yang bias dimanipulasi, dan manipulasi terhadap variable independen akan mempengaruhi variable dependennya. Mengacu pada jurnal acuan utama dalam penelitian ini, bahwa terdapat tiga variabel independen yaitu transformational leadership style, transactional leadership style, dan passive/avoidant leadership style.

b. Variabel Dependen

Variabel dependen adalah variabel yang diukur, diprediksi, atau sebaliknya dimonitori

dan diekspektasikan terpengaruh oleh manipulasi variabel independen (Cooper, 2011). Berdasarkan pada jurnal acuan utama dari penelitian ini, variabel dependennya adalah organization commitment.

Operasionalisasi variabel

gaya

\section{kepemimpinan transformasional}

Variabel gaya kepemimpinan tranformasional pemimpin/pemilik UKM diukur menggunakan alat ukur yang dikembangkan oleh penelitian berdasarkan dimensi variabel transformasional.

Operasionalisasi variabel

gaya kepemimpinan transaksional

Variabel gaya kepemimpinan transaksional pemimpin/pemilik UKM diukur menggunakan alat ukur yang dikembangkan oleh penelitian berdasarkan dimensi variabel transaksional.

\section{Operasionalisasi variabel gaya kepemimpinan pasif \\ Variabel gaya kepemimpinan pasif pemimpin/pemilik UKM diukur menggunakan alat ukur yang dikembangkan oleh penelitian berdasarkan dimensi variabel pasif.}

\section{Operasionalisasi variabel komitmen afektif}

Variabel komitmen afektif diukur menggunakan alat ukur yang dikembangkan oleh Allen \& Meyer (1990).

$\begin{aligned} & \text { Operasionalisasi variabel komitmen } \\ & \text { berdasarkan norma }\end{aligned}$
Variabel komitmen berdasarkan
norma diukur menggunakan alat ukur yang
dikembangkan oleh Allen \& Meyer (1990).
Alat ukur tersebut terdiri dari 8 pertanyaan,
sebagai berikut:




\section{Operasionalisasi}

variabel

\section{komitmen}

\section{keberlanjutan}

Variabel komitmen keberlanjutan diukur menggunakan alat ukur yang dikembangkan oleh Allen \& Meyer (1990).

\section{Metode Analisis Data}

Data primer dalam penelitian ini diolah menggunakan metode regresi logistik dengan perangkat lunak SPSS (Statistical Product and Service Solutions). Metode SPSS dipilih karena dapat digunakan sebagai alat analisis data pada riset sosial. Biasanya data yang digunakan adalah data cross section (data yang didapatkan sekali / one point in time). Asumsi dalam regresi logistik antara lain adalah:

Regresi logistik tidak membutuhkan hubungan linear antar variabel bebas dengan variabel terikat.

1. Regresi logistik dapat menyeleksi hubungan karena menggunakan pendekatan non linear log transformasi untuk memperbaiki odds ratio. Odd dalam regresi logistik sering dinyatakan sebagai probabilitas.

2. Variabel bebas tidak memerlukan asumsi multivariate normality.

3. Asumsi homokedestitas tidak diperlukan.

4. Variabel bebas tidak perlu diubah ke dalam bentuk metric (interval atau rasio).

\section{HASIL PENELITIAN}

Peneliti melibatkan 60 responden dari 7 unit UKM di wilayah Depok, Jawa Barat. Data demografi yang diidentifikasikan dalam kuesioner diantaranya adalah jenis kelamin, usia, status perkawinan, pendidikan terakhir, dan lama bekerja. Dari enam puluh responden diperoleh $70 \%$ adalah laki-laki dan 30\% sisanya adalah perempuan. Menurut tingkat pendidikan terakhir diperoleh 20\% karyawan adalah lulusan sekolah dasar (SD), 31,7\% adalah lulusan SMP, 45\% adalah lulusan SMA, dan masing-masing 1,7\% adalah lulusan D3 dan S1. Enam puluh responden yang dilibatkan dalam penelitian ini 38,3\% sudah bekerja di UKM bersangkutan selama lebih dari 3 tahun, 15\% sudah bekerja selama lebih dari 1 tahun, 23,3\% sudah bekerja selama 1 tahun dan sisanya yaitu sebesar 23,3\% termasuk kedalam karyawan baru yaitu bekerja selama 3 sampai 6 bulan.

Penemuan dalam penelitian ini diidentifikasi melalui pengujian hipotesis untuk menguji pengaruh variabel independen terhadap variabel dependen. Peneliti melakukan pengujian hipotesis menggunakan analisis regresi logistik. Sebelum melakukan analisis regresi logistik, peneliti melakukan uji validitas dan reliabilitas untuk mengevaluasi kualitas data yang dihasilkan dari penggunaan instrument penelitian dan untuk mengetahui akurasi data yang dikumpulkan dari penggunaan instrumen.

Reliabilitas dilihat dari nilai Cronbach's Alpha, apabila nilai Cronbach's Alpha lebihdari sama dengan 0,6 maka indikator reliabel untuk digunakan. Sedangkan validitas dilihat dari nilai KMO, indikator dikatakan valid apabila nilai KMO lebih dari sama dengan 0,5. Variabel transformational leadership style memiliki 14 indikator yang seluruhnya valid 
dan reliabel, variabel transactional leadership style memiliki 7 indikator yang seluruhnya valid dan reliabel, dan tiga indikator pada variabel passive/avoidant leadership style yang juga valid dan reliabel seluruhnya. Sedangkan kosep organization commitment memiliki 3 variabel yaitu affective commitment memiliki 8 indikator yang seluruhnya valid dan reliable, variabel normative commitment dengan 8 indikator yang valid dan reliabel, serta variabel continuance commitment yang memiliki 8 indikator tetapi hanya 2 variabel yang valid dan reliabel.

\section{Analisis Regresi Logistik}

Hipotesis satu adalah gaya kepemimpinan transformasional berpengaruh positif terhadap komitmen afektif. Berdasarkan hasil analisis regresi logistik, nilai percentage correct pada classification table di Bloc o ke nilai percentage correct pada Block 1 mengalami peningkatan yaitu, dari 76,7 pada Block o menjadi 90,0 pada Block 1. Nilai signifikansinya adalah sebesar 0,002 hal ini menunjukan bahwa model pada hipotesis adalah fit dan signifikan sehingga hipotesis satu diterima. Nilai $\operatorname{Exp}(B)$ adalah sebesar 1726,6 sedangkan b pada tabel variables in the equation bernilai positif, hal ini berarti bahwa gaya kepemimpinan transformasional berpengaruh positif terhadap komitmen afekif.

Hipotesis kedua dalam penelitian ini adalah gaya kepemimpinan transformasional berpengaruh positif terhadap komitmen normatif. Merujuk pada hasil analisis regresi logistik, nilai percentage correct pada classification table di Bloc o ke nilai percentage correct pada Block 1 tidak mengalami perubahan (konstan) yaitu, sebesar 58,3. Dengan demikian model pada hipotesis kedua tidak fit dan tidak signifikan, sehingga hipotesis kedua ditolak.

Hipotesis ketiga adalah gaya kepemimpinan transaksional berpengaruh positif terhadap komitmen kelanjutan. Berdasarkan hasil analisis regresi logistik, nilai percentage correct pada classification table di Bloc o ke nilai percentage correct pada Block 1 adalah konstan yaitu sebesar 60,0. Dengan demikian model pada hipotesis ketiga tidak fit dan tidak signifikan, sehingga hipotesis ketiga ditolak.

Hipotesis keempat adalah gaya kepemimpinan passive/avoidant berpengaruh negatif terhadap komitmen afektif. Berdasarkan hasil analisis regresi logistik, nilai percentage correct pada classification table di Bloc o ke nilai percentage correct pada Block 1 adalah konstan yaitu sebesar 76,7. Dengan demikian model pada hipotesis keempat tidak fit dan tidak signifikan, sehingga hipotesis keempat dalam penelitian ini ditolak.

\section{Diskusi}

Penelitian yang dilakukan oleh Sharon Clinebell, Vida Skudiene, Renata Trijonyte, dan James Reardon tentang pengaruh gaya kepemimpinan terhadap komitmen organisasi karyawan dalam sebuah organisasi memprediksikan terdapat pengaruh positif gaya kepemimpinan transformasional terhadap komitmen afektif dan normatif, terdapat pengaruh positif gaya kepemimpinan transaksional terhadap komitmen 
keberlanjutan, dan terdapat pengaruh negatif gaya kepemimpinan passive/avoidant terhadap komitmen afektif. Dalam penelitian pengaruh gaya kepemimpinan terhadap komitmen karyawan UKM wilayah Depok, Jawa Barat dalam makalah ini mengajukan hipotesis yang sama dengan jurnal acuan berjudul "Impact of Leadership Style on Employee Organization Committment' (Clinebell, 2013).

Empat hipotesis dalam penelitian ini diindentifikasi dengan menggunakan analisis regresi logistik. Berdasarkan analisis regresi yang telah dilakukan terdapat 3 hipotesis yang ditolak yaitu hipotesis 2 , hipotesis 3, dan hipotesis 4. Komitmen organisasi karyawan UKM terhadap oganisasi (UKM) tidak hanya dipengaruhi olah gaya kepemimpinan founder atau pemimpin UKM saja. Penelitian mengenai "Pengaruh Insentif Non Financial (Job enrichment dan employee recognition) Terhadap Kepuasan Kerja dan Komitmen Organisasi Karyawan” (Idris, 2010) menjelaskan bahwa komitmen organisasi karyawan secara signifikan dipengaruhi oleh job enrichment. Hal ini menunjukan dengan karyawan memiliki kebebasan dalam melaksanakan pekerjaan dan mengevaluasi hasil kerjanya akan mendorong karyawan untuk memiliki kepedulian terhadap masa depan organisasi tempat mereka bekerja. Selain itu, pekerjaan yang menarik juga merupakan pendorong bagi karyawan untuk tetap berada dalam organisasi dan yang terpenting adalah karyawan merasa memiliki dan bangga dengan organisasi di mana mereka bekerja (Idris, 2010).
Penemuan mengenai komitmen organisasi dipengaruhi oleh job enrichment ditegaskan oleh Andreas Angkowidjojo dalam penelitiannya mengenai pengaruh job enrichment terhadap motivasi, kepuasan kerja, dan komitmen organisasi. Hasil penelitiannya menjelaskan bahwa dengan meningkatnya job enrichement, maka meningkat pula komitmen organisasi karryawan. Dengan demikian dapat disimpulkan bahwa komitmen organisasi karyawan tidak hanya dipengaruhi oleh gaya kepemimpinan, tetapi teradap faktor lain yaitu job enrichment yang juga berpengaruh signifkan terhadap komitmen organisasi karyawan.

\section{KETERBATASAN PENELITIAN}

Dalam penelitian ini menggunakan responden karyawan UKM dari beberapa unit UKM dipilih secara acak di wilayah Depok, Jawa barat yang masing-masing karyawan memiliki persamaan dalam hal bidang pekerjaan dengan beberapa diferensiasi. Diferensiasi antar responden dikarenakan unit UKM tempat bekerja berbeda-beda dengan gaya kepemimpinan masing-masing atasannya (pemimpin/founder UKM) berbeda pula. Keterbatasan pada data yang terkumpul juga terjadi karena tingkat pendidikan karyawan UKM yang menjadi responden dalam penelitian ini. Karyawan UKM yang menjadi sampel dalam penelitian ini mayoritas memiliki tingkat pendidikan SD sampai dengan SMA. Penelitian ini bertujuan untuk mengetahui pengaruh gaya kepemimpinan terhadap komitmen karyawan, sehingga metode pengolahan data yang seharusnya 
digunakan adalah regresi linear pada perangkat lunak SPSS. Namun pada pengujian terhadap asumsi klasik sebelum melakukan uji regresi tidak terpenuhi sehingga peneliti menggunakan uji regresi logistik sebagai alternatif dalam melakukan pengolahan data.

\section{KESIMPULAN}

Penelitian ini menjelaskan pengaruh antara gaya kepemimpinan transformasional, transaksional, dan passive/avoidant terhadap ketiga dimensi komitmen karyawan kepada organisasi, yaitu komitmen afektif, komitmen normatif, dan komitmen keberlanjutan. Berdasarkan hasil analisis dapat diambil kesimpulan bahwa gaya kepemimpinan transformasional berpengaruh positif terhadap komitmen afektif, tetapi tidak berpengaruh terhadap komitmen normatif. Gaya kepemimpinan transaksional tidak berpengaruh komitmen berkelanjutan, dan gaya kepemimpinan passive/avoidant tidak mempengaruhi komitment afektif. Tiga

\begin{abstract}
hipotesis ditolak dalam penelitian ini, hal ini karena terdapat faktor lain diluar model penelitian yang secara signifikan mempengaruhi komitmen organisasi karyawan yaitu job enrichment.
\end{abstract}

\section{SARAN}

Apabila ada pihak yang akan melakukan penelitian dengan topik serupa, disarankan untuk meneliti UKM yang bergerak dibidang industri yang sama. Disarankan untuk menambah jumlah sampel sehingga lebih bisa menggambarkan karakteristik populasi. Menggunakan jurnal acuan yang sesuai baik dari aspek karakteristik responden maupun aspek yang lain, sehingga hasil yang diperoleh sesuai dengan jurnal acuan. Akan lebih baik jika dalam pengisian kuesioner peneliti mendampingi responden, sehingga dapat meminimalisir ketidakpahaman responden terhadap pertanyaan dalam kuesioner.

\section{DAFTAR PUSTAKA}

Clinebell, dkk. (2013). The impact of leadership style on employee organization commitment. Journal of Service Science.

Zafer. (2012). Organizational culture, leadership style and organization commitment in turkish logistics industry.

Allen, N. J. \& Meyer, J. P., (1990). The measurement and antecedents of affective, continuance and normative commitment to organization. Journal of Occupational Psychology, 63, 1-18.

Bass, B. M. (1990). From transactional to transformational leadership: Learning to share the vision. Organizational Dynamics, 18(3), 19-31. 
Mathieu, J. E. \& Zajac, D.M. (1990). A review and meta-analysis of the antecedents, correlates and consequences of organizational commitment. Psychological Bulletin, 108(2), 171-194.

Meyer, J.P., \& Allen, N.J. (1991). A three-component conceptualization of organizational commitment. Human Resource Management Review, 1, pp. 61-89.

Mowday, R.T., Steers, R. M. \& Porter, L. W. 1979. The measurement of organizational commitment. Journal of Vocational Behavior, 14, 224-247.

Yammarino, F. J. \& Bass, B. M. (1990). Long-term forecasting of transformational leadership and its effects among naval officers: In K. E. Clark \& M. B Clark (Eds.), Measures of leadership. West Orange, NJ: Leadership Library of America.

Allen, N.J. and Meyer, J.P. (1990). The measurement and antecedents of affective, continuance and normative commitment to the organization. Jounal of Occupational Psychology, 63(1), 1-18.

Becker, H. S. (1960). Notes on the concept of commitment. American Journal of Sociology, 66, 32-42.

Bučiūnien , I., \& Škudien , V. (2008) Impact of Leadership Styles on Employees' Organizational Commitment in Lithuanian Manufacturing Companies. South East European Journal of Economics and Business, 3(2), 57-65.

Flynn, S.I. (2009). Transformational \& transactional leadership. EBSCO Research Starters. Academic Topic Overviews, p. 1-6.

Meyer, J.P., \& Allen, N.J. (1991). A three-component conceptualization of organizational commitment. Human Resource Management Revierw, 1, pp. 61-89.

Burns, J.M. (1978). Leadership. New York: Harper \& Row.

Bass, B.M. and Avolio, B.J. (1994). Improving Organizational Effectiveness through Transformational Leadership. Newbury Park, CA: Sage.

Bass, B.M. (1985). Leadership and Performance beyond Expectation. New York: The Free Press.

Clark, D. (1997) Big Dog Leadership. Retrieved on Nov. 27, 2011 on http://www.nwlink.com/ donclark/leader/leader.html.

Cooper, Schindler. (2011). Business Research Methods. 12th edition.The McGraw-Hill, Wittenberg University.

Sudarno. (2011). Kontribusi usaha mikro, kecil, dan menengah (UMKM) dalam penyerapan tenaga kerja di Depok. Jurnal Ekonomi dan Bisnis, Vol 10 no. 2, p. 139-146.

Wahyuningrum, P. Sukmawati, A. Kartika, L. (2014). Peningkatan kinerja usaha kecil dan menengah (UKM) cluster kerajinan di kota depok menggunakan the house model.

Ongkowidjojo, A. Pengaruh job enrichment terhadap motivasi, kepuasan kerja, dan komitmen organisasional pada pt nutrifood indonesia surabaya. 
Idris, A. (2010). Pengaruh insentif non financial (job enrichment, employee recognition) terhadap kepuasan kerja dan komitmen organisasi karyawan. Journal of Marketing, p.07.

Dmd. "Masalah UKM Indonesia Tak Melulu Soal Modal”. Sindonews.com 4 Agustus 2015. < http://ekbis.sindonews.com/read/1029310/34/masalah-ukm-di-indonesia-tak-melulu-soal-modal$1438676540>$

Ranchman. "Kesulitan Pemasaran dan Manajemen, UMKM di Banten Menghadapi Masalah Berganda”. Bisnis.com $13 \quad$ April $2015 . \quad$ http://jakarta.bisnis.com/read/20150413/383/422328/kesulitan-pemasaran-dan-manajemenumkm-di-banten-hadapi-masalah-berganda $>$

"Pertumbuhan Ekonomi Dorong Ekspansi UKM". Berita Industri. Kementrian Perindustrian Republik Indonesia.

< www.kemenperin.go.id/artikel/5774/Pertumbuhan-Ekonomi-Dorong Ekspansi-UKM >

"Pasar Modern Wajib Sediakan 2 Persen Lahan bagi UMKM". Wartakota.tribunnews 31 Juli 2015. $<$ wartakota.tribunnews.com/2015/07/31/pasar-modern-wajib-sediakan-2-persen-lahan-bagi umkm>

"Logistic Regression Chapter 1", Teori Online, References, Tutorial, and Discussion. < https://teorionline.wordpress.com/2011/05/15/logistic-regression-chapter-1/> 